\title{
THE CUTTER POLIO VACCINE INCIDENT: A CASE STUDY OF MANUFACTURERS' LIABILITY WITHOUT FAULT IN TORT AND WARRANTY
}

IN spring of 1955 Cutter Laboratories released six lots of Salk anti-poliomyelitis vaccine that contained live polio virus. ${ }^{1}$ The Salk process had been expected to inactivate all the live virus used in the preparation of the vaccine, but it failed to do so. ${ }^{2}$ Cutter was unable to detect inactivated virus in the six lots of vaccine because of "fundamental weaknesses" in its safety tests. ${ }^{3}$ However, these tests seemed entirely adequate on the basis of the knowledge and experience available at that time. ${ }^{4}$ They were approved by leading scientists and were used with apparent success by Cutter's competitors." The "fundamental weaknesses" were not suspected until the tests failed to work. "However, they did fail to work, and as a result many children contracted paralytic polio. ${ }^{7}$

1. Public Health Service, U.S. Dep't of Healte, Education, anu Welfare, Report on Polionitelitis Vaccise Produced by the Cutter Laboratories (Aug. 25, 1955) (hereinafter cited as August Report); $c f$. Report of Surgeon General Lionand A. Scheele on the Status of Salk Polrovielitis Vaccine, reprinted in part in N.Y. Times, June 10, 1955, p. 12, col. 4 (hereinafter cited as JUNE REPorT). For a nontechnical narration of the widespread, highly publicized distribution of the Salk Vaccine, sec Spencer, Where Are We Now on Polio?, Saturday Evening Post, Sept. 10, 1955, p. 19; see also N.Y. Times, April 13, 1955, p. 1 \& passim. The evidence indicates that of the 17 lots of vaccine released by Cutter, 6 had infective amounts of live virus.

2. The Salk process had been developed and tested by small laboratory-produced batches of vaccine. In mass production the Salk inactivation process was not as safe as had been expected. Several manufacturers had difficulties with the inactivation process. August REPORT 5-6; N.Y. Times, June 10, 1955, p. 12, col. 3 ; Spencer, stepra note 1, at 20, 153-56.

3. August Report 5. See also Spencer, supra note 1 , at $156-57$.

4. Despite the fact that the vaccine was developed, tested and used in a matter of months instead of years, the laboratory work and the 1954 field trial indicated that the tests were entirely adequate. JUNE REPORT. However, the vaccines used in the 1954 trial had not been mass-produced.

5. See August Report 5; Spencer, supra note 1, at 153, 156-57.

6. A report on the 1954 field trial, released April 12, 1955, indicated that the vaccine was perfectly safe. After summarizing some statistics as to reactions, the report continued:

"These findings ... fail to implicate the vaccine as a significant cause of untoward reactions.

"Also bearing on the question of safety is the review of 129 cases occurring up to the first month after inoculation. Here again, there is no evidence implicating vaccine as a source of infection. Furthermore, study of the location of the paralysis failed to demonstrate any localization of involvement to the left arm, where all injections were given."

Report by Dr. Thomas Francis, Jr., April 12, 1955, reprinted in part in N.Y. Times, April 13, 1955, p. 22, cols. 2-3.

Even after some of the earliest Culter cases turned up, the Associated Press reported a strong feeling of confidence by the nation's state health officers in the safety of the Salk polio vaccine. N.Y. Times, May 1, 1955, p. 60 , col. 4.

7. An estimated 401,000 children were vaccinated with Cutter vaccine. Seventy-three 
It is doubtful whether the children who contracted polio from the infective vaccine could obtain compensation for their injuries by means of a negligence action. Such an action presupposes a failure by the defendant to use "reasonable" care. A person injured by a defective drug or medicine generally is entiled to bring a negligence action directly against the manufacturer. ${ }^{8}$ And because it is virtually impossible to prove specific acts of negligence by a drug manufacturer, most courts will permit an inference of negligence once plaintiff has proved that there was a dangerous impurity in the drug. ${ }^{9}$ However, the methods Cutter used to inactivate and test its vaccine were generally believed to assure complete removal of live virus, ${ }^{10}$ and seem to satisfy the standards of care to which the manufacturing druggist has traditionally been held. ${ }^{11}$ Therefore it is likely that Cutter will be able to overcome the usual presumptions of negligence and thereby prevent the issue from going to the jury.

Policy considerations indicate that Cutter should be liable to persons who contracted polio from live virus in the vaccine it manufactured, without regard to whether it was at "fault." 12 Biological products promise to enable society to combat presently uncontrollable virus diseases, perhaps including cancer. ${ }^{13}$ Society is best served if new biologicals are widely distributed as soon as their

contracted polio within the incubation period of 3 to 31 . days. Of these 73 cases, 46 were reported among individuals injected with vaccine from the 6 infective lots. AugusT REPORT 2 .

S. Leading cases are Hruska v. Parke, Davis \& Co., 6 F.2d 536 (8th Cir. 1925) (defective drug administered by incculation); Blood Balm Co. v. Cooper, 83 Ga. 457, 10 S.E. 118 (18\$9) (drug unskillfully compounded by manufacturing druggist) ; cf. MacPherson v. Buick Motor Co., 217 N.Y. 382, 111 N.E. 1050 (1916).

9. Once the plaintiff has shown the existence of the defect and its relation to his injury, the ncgligence leading to the defect will be presumed; and any presumption of negligence, unless rebutted, is enough to send the case to the jury. See, e.g., Cody v. Toller Drug Co., 232 lowa 475, 5 N.W.2d 824 (1942) (evidence of poison in drug held sufficient to establish negligence); Edelstein v. Cook, 108 Ohio St. 346, 140 N.E. 765 (1923) (res ipsa loquitur applied to establish prima facie case of negligence against defendant druggist).

10. See notes 3-6 supra and accompanying text. Surgeon General Leonard A. Scheele said in a newspaper interview that Cutter was operating "according to the standard," although he refused to call the Public Health Service Report of August 25, 1955, an "acquittal," an "exoneration" or a "clean bill of health." A Cutter release interpreted the Report as stating "that no negligence or incompetence could be found at Cutter Laboratories." N.Y. Times, Aug. 26, 1955, p. 1, col. 6.

11. See notes 3-6 supra and accompanying text.

On the druggist's standard of care, see, e.g., Tremblay v. Kimball, 107 Me. 53, 77 Atl. 405 (1910); Taugher v. Ling, 127 Ohio St. 142, 187 N.E. 19 (1933).

12. The term "fault" is used hereinafter to refer to actionable negligence.

Proof that the defective vaccine was the proximate cause of plaintiff's injury will, of caurse, be necessary in order to establish liability in any case. It may not always be certain whether the plaintiff contracted polio because of or in spite of the vaccine. See August Report 6.

13. Potent new biologics may soon be developed which will enable science to control such virus discases as hepatitis, influenza, encephalitis and perhaps cancer. JUNE REPORT, N.Y. Times, June 10, 1955, p. 12, col. 7. 
safety seems assured.14 However, absolute safety cannot be assured in advance of actual use. Inevitably, some standards of safety which seemed perfect will be proved in retrospect to have been faulty, and human injury will result. This injury is a cost of social progress. The cost should not be borne only by the injured persons. It should be shared by all who benefit from the harmless use of the vaccine. ${ }^{15}$ For these reasons the manufacturer should be absolutely liable $:^{16}$ he is in the best position to compensate injured persons, by insurance or otherwise $;^{17}$ and to distribute the cost of compensation or insurance, as a typical cost of the enterprise, by increasing the price paid by all persons who benefit from the use of the vaccines. ${ }^{18}$

14. Thus, society need not wait until $100 \%$ safety is absolutely assured before it can reap the benefits of medical discoveries. The standard for determining the margin of safety must, of course, be high. But it should be a standard that attempts to balance the potential danger against the prospective over-all gain. See letter from Leonard A. Scheele, Surgeon General, to Mrs. Oveta Culp Hobby, Secretary of Health, Education and Welfare, reprinted in N.Y. Times, June 10, 1955, p. 12, col. 3. Dr. Scheele, in early November 1955, estimated that there was 70 to $90 \%$ less paralytic polio among children who had received the Salk vaccine than among those in the same age groups who had not received it. N.Y. Times, Nov. 8, 1955, p. 64, col. 1 .

15. "It is the principal job of tort law today to deal with [human losses through accidents]... . The best and the most efficient way to do this is to assure accident victims of compensation, and to distribute the losses involved over society as a whole or some very large segment of it." James, Accident Liability Reconsidered: The Impact of Liability Insurance, 57 YALE L.J. 549, 550 (1948). Those who suffer injury from dcfective products are generally unprepared to meet its consequences. Escola v. Coca-Cola Bottling Co., 24 Cal. 2d 453, 462, 150 P.2d 436, 441 (1944) (Traynor, J., concurring opinion).

16. "There is a strong and growing tendency, where there is no blame on either side, to ask, in view of the exigencies of social justice who can best bear the loss, and hurre to shift the loss by creating liability where there has been no fault." Pound, The End of Law As Developed in Legal Rules and Doctrines, 27 Harv. L. Rev. 195, 233 (1914); see Jeanblanc, Manufacturers' Liability to Persons other than Their Immediate Vendees, 24 VA. L. Rev. 134, 157 (1937).

Other possibilities for compensation of the injured victims are individual insurance or government subsidization. Individual insurance is far from universal, and would supply compensation in only a small percentage of the cases, possibly where it is least needed. And blanket governmental compensation might remove some of the manufacturer's incentive to be sure that no defects are negligently introduced. See notes 47,53 infra and accompanying text.

17. Products liability insurance is readily available to producers of goods. The manufacturer is in the ideal position to estimate the prospective loss through accident, if cstimation is at all possible. The insurance company would base the cost of its premiums on such an actuarial reckoning. Rates would, of course, vary between manufacturers if any showed a marked deviation from the normal actuarial rate. For a short summary of the contents and the availability of products liability policies, see Dickerson, Pronctis Liability and the Food Consumer 265-69 (1951). Many large manufacturers might prefer to insure themselves by maintaining a reserve to compensate injured plaintiffs.

18. "The administration of losses in this way may entirely change evaluations of what is fair. If a certain type of loss is the more or less inevitable by-product of a desirable but dangerous form of activity, it may well be just to distribute such losses among all the beneficiaries of the activity though it would be unjust to visit them severally upon these individuals who had happened to be the faultless instruments causing them." James, stpra 
Although probably not "negligent," Cutter may be held liable for injuries that resulted from its breach of an implied warranty that the vaccine it produced would be fit for the inoculation of human beings. Sellers of goods are bound by a warranty, implied from the contract of sale or imposed by operation of law as a matter of public policy, that the goods they sell are fit for the purpose for which they will be used. ${ }^{19}$ The warranty is imposed because the seller knows or should know the buyer's purpose and because the buyer relies or must rely on the seller's skill and judgment. ${ }^{20}$ Since the seller is

note 15 , at 550 . For an elaboration on how wide distribution of losses benefits society, see id. at 550 n.1.

If it is a type of harm typically or foreseeably caused by the manufacturer's activity, he can reasonably insure against the loss and then recover the cost by charging a somewhat higher price for the vaccine. See Enrenzweig, Negligence Without Fault S1 (1951) ; see also Cushing v. Rodman, S2 F.2d 864, 869 (D.C. Cir. 1936); Escola v. Coca-Cola Bottling Co., 24 Cal. 2d 453, 462, 150 P.2d 436, 441 (1944) (concurring opinion).

Opponents of strict liability argue that it tends to discourage people from performing socially advantageous activity that is accompanied by a high risk of loss. See Prosser, ToRTs 332 (2d ed. 1955). It is at least doubtful that this argument has proved true in the past, and it is unlikely that strict liability would dissuade drug manufacturers from future production of new biologicals. The risk of loss is insurable, the price of the product is controlled by the producers, and there is a guaranteed market of unusually large size. Drug manufacturers already are extensively regulated by statute, see generally, TouLMIN, Foons, Drugs and Cosmetics (1942), and they are subject to heavy liability in tort for defective products, see note 9 supra and accompanying text.

19. Uniforar Sales Act § 15(1); Uniform Comarercial Code \$ 2-315. The Sales Act and the Commercial Code merely codify the common law, and similar warranty provisions apply in those states where neither statute has been enacted. See, e.g., Cliett v. Lauderdale Biltmore Corp., 39 So. 2d 476 (Fla. 1949) (restaurateur held to warrant food served) ; Stanfield v. F. W. Woolworth Co., $143 \mathrm{Kan} .117,53$ P.2d 878 (1936) (same).

"[T]he obligation is imposed upon the seller, not because he has assumed it voluntarily, but because the law attaches such consequences to his conduct irrespective of any agreement. ..." Prosser, Torts 493 (2d ed. 1955). See also Jacob E. Decker \& Sons v. Capps, 139 Tex. 609, 612, 164 S.W.2d 828, 830 (1942) (contaminated food products); Bekkevold v. Potts, 173 Minn. 87, 89, 216 N.W. 790, 791 (1927) (truck and tractor); 1 Williston, SALES $\$ 197$ (rev. ed. 1948).

20. Uniform Sales ACt $\$ 15(1)$; Untforar Commerctal Code $\$ 2-315$.

Actual knowledge is not necessary if the seller has reason to know the buyer's intended purpose. Uniform Commercial Code $\$ 2-315$, Comment 1 . The same effect is given to the Sales Act, although it is not as explicit as the Code. UNIFORM SALES ACr $\$ 15(1)$. See Vaccarino v. Cozzubo, 181 Md. 614, 619, 31 A.2d 316, 319 (1943) (sale of meat); Rinaldi v. Mohican Co., 225 N.Y. 70, 73, 121 N.E. 471, 472 (1918) (same).

If no particular purpose is made known to the seller, he may be held to an implied warranty that the goods are of "merchantable quality." See UNIFoRM SALES ACT $\$ 15(2)$; Unirorm Conmerctal Code $\$ 2$-314. "Mferchantable" means that the goods are fit for the purposes for which they are ordinarily used. Ryan v. Progressive Grocery Stores, 255 N.Y. 388, 393, 175 N.E. 105, 106 (1931) (pin in packaged loaf of bread); Giant Mfg. Co. v. Yates-American Mach. Co., 11 F.2d 360, 365 (Sth Cir. 1940) (defective air-cooling unit); Uniforas Coximercial Code $\$ 2-314(2)$ (c). This may amount to a warranty of fitness for a particular purpose. Prosser, The Implied Warranty of Merchantable Quality, 27 Minn. L. Kev. 117, 132-34 (1943); see also Ryan v. Progressive Grocery Stores, supra.

Many courts impose an implied warranty of fitness for human consumption without requiring specific proof of purpose or reliance. These courts do not go to the Sales Act 
"absolutely liable," the buyer may recover damages for any loss proximately resulting from the breach, including compensation for personal injury, ${ }^{21}$ without alleging or proving that the seller was negligent. ${ }^{22}$ However, the warranty theory of liability is usually subject to commercial doctrines that restrict its application. ${ }^{23}$ For example, an implied warranty of fitness will be imposed only when there is a "sale" of goods, and will be extended only to parties who are in "privity" with the warrantor. ${ }^{24}$ Some courts have rejected one or both of these doctrinal limitations on the ground that the warranty of fitness for human consumption, based on the policy of protecting human health, must be treated differently from the commercial warranty of the Sales

for their authority but only to the public policy of protecting the health and life of society's members. See, e.g., Cushing v. Rodman, 82 F.2d 864 (D.C. Cir. 1936) (pebble in roll served by restaurant); Jacob E. Decker \& Sons v. Capps, 139 Tex. 609, 164 S.W.2d \$28 (1924) (contaminated meat in can) ; note 46 infra and accompanying text. Thus "reliance," in effect, has been inferred from a relationship between buyer and seller in which as a practical matter the seller alone can prevent or detect dangerous defects.

21. Untrora Sales Act $\$ 69(6)$; Uniform CoMmierctal Code $\$ \$ 2-714(1)$, (3), 2-715(2) (b). Consequential damages for breach of implied warranty must be foreseeable. But if the seller knows how the goods are ordinarily used for a particular purposic (as he does in an implied warranty situation), he is on notice that the damages may be more than the difference in value between satisfactory and unsatisfactory goods. McLachlan v. Wilmington Dry Goods Co., 41 Del. 378, 384-85, 22 A.2d 851, 854 (1941) ; Ryan v. Progressive Grocery Stores, 255 N.Y. 388, 395, 175 N.E. 105, 107 (1931). These damages may include compensation for personal injury. E.g., Friend v. Childs Dining Hall Co., 231 Mass. 65, 120 N.E. 407 (1918); 1 WILliston, SALES $\$ 242 \mathrm{~b}$ \& n.6 (rev. ed. 1948) (collecting citations). The buyer may also recover for damage to property. E.g., Ingraham v. Associated Oil Co., 166 Wash. 305, 6 P.2d 645 (1932); 3 Wruliston, op. cit. stupra, $\S 614 \& \mathrm{n} .2$.

22. Kenower v. Hotels Statler Co., 124 F.2d 658, 662 (6th Cir. 1942); Lundquist v. Coca-Cola Bottling, Inc., 42 Wash. $2 d$ 170, 172, 254 P.2d 488, 489-90 (1953). See 1 Williston, op. cit. supra note $21, \S 237 \&$ n.13.

23. Although logically possible, it appears inconceivable that a court would hold that Cutter did not warrant the fitness of its vaccine for human use. See notes 19-22 supra and accompanying text. There are a few old cases, however, which seem to be precedent for the proposition that an implied warranty is not available to persons injured by defective drugs. E.g., Brown v. Marshall, 47 Mich. 576,11 N.W. 392 (1882); Willson v. Faxon, Williams, \& Faxon, 138 App. Div. 366, 122 N.Y. Supp. 783 (4th Dep't 1910); cf., Henderson v. National Drug Co., 343 Pa. 601, 23 A.2d 743 (1942) (semble).

24. See, generally, Note, Should the Doctrine of Implied Warrantics Be Limitcd to Sales Transactions?, 2 VAND. L. Rev. 675 (1949); Spruill, Prizity of Contract as a Requisite for Recovery on W'arranty, 19 N.C.L. Rev. 551 (1941).

Another potential weakness in the contractual doctrine is that the seller may expressly disclaim the existence of any implied warranties. Vandiver v. B. B. Wilson \& Co., $244 \mathrm{Ky}$. 601, 608, 51 S.W.2d 899, 902 (1932) (Sales Act; express disclaimer of liability for mechanical failure of air compressor upheld); UnIForar CoMrMercial Code $\$ 2-316(2)$. In the only reported case involving a disclaimer of a warranty of fitness for human consumption, a lower New York court held the disclaimer invalid as against public policy. Linn v. Radio Center Delicatessen, Inc., 169 Misc. 879, 9 N.Y.S.2d 110 (Sup. Ct. 1939) (tack in pastry). Where the manufacturer is clearly without fault, however, a court might uphold a disclaimer. 
Act or the common law. ${ }^{25}$ But in most jurisdictions the "sale" and "privity" limitations are still applied strictly, and will hamper or defeat recovery by persons injured by infective vaccines.

The contract doctrine of privity may create several difficulties for injured persons who obtained infective vaccine under varying circumstances. In the most common situation, where children obtained vaccine in the free inoculation program sponsored by the National Foundation for Infantile Paralysis, no contract existed between child and Foundation; and the child was of course not a party to the contract between Foundation and manufacturer. ${ }^{26}$ However, "third party beneficiary" doctrine may enable such a child to sue the manufacturer in contract. Under this doctrine, any implied warranty action availalsle to the buyer in a two-party contract of sale is equally available to third parties, or to a class of third parties, who are clearly designated as the intended beneficiaries of a multi-party transaction. ${ }^{2 \pi}$ The Foundation's intent to benefit all first and second grade school children in the nation was known to vaccine sellers, ${ }^{28}$ and the class of beneficiaries, though large, seems to have been designated with sufficient particularity.

Where vaccine was obtained from a doctor or hospital, rather than from the National Foundation, two privity problems arise. Thus, a child who is injured will seldom if ever have contracted to receive the inoculation; ordinarily the contracting parties will have been the child's parents. In this situation, third party doctrine should enable the child to overcome privity objections to a suit against the doctor or hospital, since both intent to benefit and clear

25. See excellent discussion in Jacob E. Decker \& Sons v. Capps, 139 Tex. 609, 617-20, 164 S.W.2d 828, 831-32 (1942); notes 29, 31, 39 infra.

26. Cutter and other manufacturers sold the Polio Foundation enough polio vaccine to inoculate all first and second grade students in the country. The vaccine was distributed through the various state health departments. Spencer, Where Are We Now on Polio?, Saturday Evening Post, Sept. 10, 1955, pp. 19, 20-21, 152. The arguments outlined in the text would apply similarly to a program such as New York City's, which provides for free inoculations for all under twenty. N.Y. Times, April 17, 1955, $\$ 1$, p. 1, col. 6 .

27. The contract must be "so expressed as to give the promisor reason to know that [the] benefit is contemplated by the promisee as one of the motivating causes of his making the contract." \& Conbro, Contracts 18 (1951) (collecting citations). "The renudies available to a beneficiary are exactly the same as would be available to him if he were a contractual promisee of the performance in question." $4 \mathrm{id}$. $\$ 810$ at 230 . This has been held to apply specifically to implied warranties. E.g., Ward Baking 'Co. v. Trizzino, 27 Ohio App. 475, 161 N.E. 557 (1920) (manufacturer liable for injuries caused to consumer by needle in cake; consumer held third party beneficiary of manufacturer's sale to retailer); Dryden v. Continental Baking Co., 11 Cal. 2d 33, 77 P.2d $\$ 33$ (1938) (wife collects from manufacturer for injury caused by glass in bread husband purchased from retailer) (dictum). See also UNIForM CoMmercial CoDE $\$ 2-318$.

"If a class of persons is clearly designated as beneficiaries, an individual of that class can maintain suit though not specifically named." 4 CORBIN, Contracts $\$ 781$ at 72 (1951) (collecting citations). In Tennessee Coal, Iron \& R.R. v. Sizemore, 258 Ala. 344, 12 So. $2 \mathrm{~d} 459$ (1952), an employee sued as third party beneficiary of a bargaining contract letween the union and employer, and collected damages for personal injury resulting frum the latter's failure to install a proper ventilating system.

22. See note 26 supra. 
designation of beneficiary would exist. ${ }^{29}$ Third party doctrine is not likely, however, to enable the injured person, whether adult or child, to proceed against the vaccine manufacturer. Intent by the contracting doctor or hospital to benefit the patient will be less clear than the intent of parents or National Foundation to benefit children. ${ }^{30}$ And the class, made up of future patients, will be less indentifiable. Moreover, courts may be less inclined to stretch doctrine to meet this situation, since a decision adverse to the patient would not foreclose all possibility of compensation; it would defeat only the direct action against the manufacturer. Therefore, except in the minority of jurisdictions which disregard privity altogether on grounds of public policy, ${ }^{31}$ the injured person is likely to be limited to an implied warranty action against the doctor or hospital from whom he obtained the vaccine.

The success of a warranty suit against the doctor or hospital that inoculated an injured person is likely to depend on whether a court finds that the inoculation was a "sale" of vaccine or a contract for "services." Most courts will not impose an implied warranty upon goods that are "merely furnished" ancillary

29. In at least twelve states children can sue in implied warranty even though their parents were the contracting parties. Most of these courts do not bother with doctrinal niceties, but merely override the privity requirement on the basis of public policy. DickERSoN, Products Liability and THe Food Consuner $\$ 1.22$ at 65 \& n.3 (1951). At any rate, privity will be no problem to children who fit within the factual category of third party beneficiaries. See note 27 supra. And the children who were inoculated by the hospitals or doctors paid by their parents were undoubtedly the known beneficiaries of the parents' transaction.

Even where the privity requirement is ostensibly enforced, an agency theory may be accepted to circumvent the difficulty. This generally has been applied only where the wife is the agent of the husband. Dickerson, op. cit. supra, at 65-67 \& nn.5-9. But sec Bowman v. Great Atlantic \& Pac. Tea Co., 284 App. Div. 663, 133 N.Y.S.2d 904 (4th Dep't 1954), aff'd, 308 N.Y. 780, 125 N.E.2d 165 (1955) (sisters).

30. In at least one case a purchaser from a retailer has been held to be a third party beneficiary of the contract between the manufacturer and the retailer. Ward Baking Co. v. Trizzino, 27 Ohio App. 475, 161 N.E. 557 (1920). But use of the third party theory in this context was criticized in Comment, 23 CALIF. L. REv. 621, 625 (1935) ; Note, 22 Wask. U.L.Q. 406,417 n.71 (1937).

31. "The general rule is that a manufacturer or seller of food, or other articles of personal property, is not liable to third persons, under an implied warranty, who have no contractual relations with him. The reason for this rule is that privity of contract does not exist between the seller and such third persons, and unless there be privity of contract, there can be no implied warranty." Chysky v. Drake Co., 235 N.I. 468, 472, 139 N.E. 576, 578 (1923). This is the rule in about 17 states and the District of Columbia. Dickerson, op. cit. supra note $29, \S 2.1$ \& n.3 (collecting citations). But by 1955 there were at least 15 states where the absence of privity would not bar a suit. Prosser, TorTs 508-09 (2d ed. 1955) (collecting citations); see also DICKerson, op. cit. supra, $\$ 2.2 \&$ nn.1-8 (collecting citations from all jurisdictions as of 1951).

The courts that override the privity requirement do so on the grounds of public policy, but the rationale often differs. Some courts find a warranty that "runs with the goods" or "inures" to the consumer's benefit. Others call the consumer a third party beneficiary of the contract between retailer and manufacturer. A few simply ignore or brush aside the problem. Most point out the need for an exception to the usual privity rule on the grounds of public policy alone. Ibid. 
to a contract for services, ${ }^{32}$ and it might be argued that the inoculation was administered under a contract for services rather than a sale of vaccine. Authority for this argument may be found in the recent $B a d$ Blood ${ }^{33}$ case, where the New York Court of Appeals concluded that blood administered by a hospital in the course of a transfusion carried no implied warranty of fitness. The blood contained infectious hepatitis virus which medical science is currently unable to prevent or detect in blood. ${ }^{34}$ The court held that the blood had not been sold but had merely been supplied to the patient incidental to a contract for the hospital's services. ${ }^{35}$ However, many courts may ignore the rationale of the Bad Blood case ${ }^{36}$ and follow the ready analogy of the restaurant cases. The older theory, that food served in a restaurant did not carry a warranty of fitness because it was merely supplied pursuant to a contract for services, has now been repudiated by most modern courts. ${ }^{37}$ These courts usually find that the restau-

32. E.g., Merrill v. Hodson, \&S Conn. 314, 91 Atl. 533 (1914) (restaurant transaction held a contract for service, therefore no implied warranty imposed); Nisky v. Childs Co., 103 N.J.L. 464, 135 Atl. S05 (1927) (same); Foley v. Dove, 101 A.2d 841 (Munic. Ct. App., D.C. 1954) (wall built under a construction contract held to carry no implied warranty because supplied under a service contract). The Merrill case was overruled in effect by ConN. GEN. STAT. \$2161c (Supp. 1953), but the statute first labels the transaction a sale of food and then says an implied warranty exists. Most of the restaurant cases that impose an implied warranty do so only after labeling the transfer of food a sale. E.g., Goetten v. Owl Drug Co., 6 Cal. $2 \mathrm{~d} 683$, 59 P.2d 142 (1936) ; Temple v. Keeler, 23S N.Y. 344, 144 N.E. 635 (1924). But see cases cited note 39 infra.

33. Perlmutter v. Beth David Hospital, 308 N.Y. 100, 123 N.E.2d 792 (1954).

34. Medical science has not yet developed methods for the detection or inactivation of a small percentage (0.45-1.00\%) of hepatitis virus in human whole blood. Neefe et al., Carriers of Hepatitis Virus in the Blood and Viral Hepatitis in Whole Blood Recipients, $154 \mathrm{~J}$. Arr. MEo. Ass'N 1066 (1954). Cf. Perlmutter v. Beth David Hospital, supra note 33, at 106-07, 123 N.E.2d at 795.

35. "The essence of the contractual relationship between hospital and patient is readily apparent; the patient bargains for, and the hospital agrees to make available, the human skill and physical materiel of medical science to the end that the patient's health be restored.

"Such a contract is clearly one for services. . . Concepts of purchase and sale cannot separately be attached to the healing materials-such as medicines, drugs, or indeed, bloud-supplied by the hospital for a price as part of the medical services it offers." Perlnutter v. Beth David Hospital, supra note 34 , at 104, 123 N.E.2d at 794. The "essence" test used by the court in determining the sale or service question is not the test generally uscd in the United States. Usually, courts apply the "Massachusetts Rule": goods are not "sold" if they are specially manufactured for the buyer and are not resaleable in the ordinary course of the seller's trade. See Note, 40 CoRN. L.Q. S03, 805-06 (1955) (collecting citations).

36. The Bad Blood case has been soundly criticized on the basis of its policy and dactrinal approach. Note, 103 U. PA. L. Rev. 833 (1955). But the rationale of the decision can be accepted, and a preventive inoculation nevertheless distinguished from getting a transfusion in the course of an operation. Even if service is the essence of an operation, it is still arguable that the essence of a polio inoculation is the sale of the vaccine.

37. At the present time 21 jurisdictions impose an implied warranty on food served in a restaurant; 6 have explicitly held contra. The remaining 22 have not decided the question. Annot., 7 A.L.R.2d 1027 (1949) ; A.L.R.2d Supplement Service 286 (1955). 
rant transaction results in a "sale" of food." A few have gone even further, recognizing explicitly that the imposition of an implied warranty of fitness for human consumption depends on considerations of policy, and does not require a technical finding of "sale."39 It seems likely that a number of courts would extend the rationale of these cases to the vaccine context.

The doctrinal label of "service" or "sale" which a court affixes to the polio inoculation will probably depend upon a policy judgment whether doctors and hospitals should be brought into court as warrantors. Courts may be reluctant to subject doctors and hospitals to warrantors' liability for two reasons. First, some courts may believe that warranty liability would contravene the policy of hospital immunity from tort actions. 40 However, hospital immunity has been severely criticized in recent years, ${ }^{41}$ and most courts have either rejected the policy or strictly limited its applicability. ${ }^{42}$ Secondly, most courts would be

38. E.g., Goetten v. Ow1 Drug Co., 6 Cal. 2d 683, 59 P.2d 142 (1936); Temple v. Keeler, 238 N.Y. 344,144 N.E. 635 (1924).

39. See, e.g., Cushing v. Rodman, 82 F.2d 864, 868 (D.C. Cir. 1936); Amdal v. F. W. Woolworth Co., 84 F. Supp. 657, 659-60 (N.D. Iowa 1949) ; Cliett v. Lauderdale Biltmore Corp., 39 So. 2d 476, 478 (Fla. 1949). See 1 Williston, Sales 640-41 (rev. ed. 1948).

It would seem unnecessary to require a finding of a sale. The Sales Act and the Code apply only to sales, Uniforu Sales Act $\$ 15$; Uniform Commerchal Cone $\$ \$ 2-314$, $2-315$, but they do not appear to preclude the imposition of warranties in other contexts. The law of implied warranties developed within the law of sales partly because a sale was the most common situation in which one person supplied goods to another. HARPER \& JAMES, unpublished manuscript for forthcoming treatise on the law of torts. Originally, liability for breach of warranty sounded in tort. Ames, History of Assumpsit, 2 Harv. L. Rev. 1, 8 (1888) ; Prosser, Torrs 493-94 (2d ed. 1955); 1 Wiluiston, op. cit. supra, § 195. Legal writers have therefore welcomed judicial extension of warranty doctrine, when justified by considerations of policy, to transactions in which goods were supplied outside the traditional sales context. Note, Should the Doctrine of Implied Warranties Be Limited to Sales Transactions?, 2 VANd. L. Rev. 675 (1949).

40. See, generally, Annot., Immunity of Nongovernmental Charity from Liability for Damages in Tort, 25 A.L.R.2d 29 (1952) ; Annot., Inmunity from Liability for Damages in Tort of State or Governmental Unit or Agency in Operating Hospital, 25 id. at 203.

41. E.g., Prosser, Torts 770-88 (2d ed. 1955) ; Harper, Torts $\$ 294$ (1933) ; James, Tort Liability of Governmental Units and Their Officers, 22 U. CHI. L. REv. 610 (1955). See President \& Directors of Georgetown College v. Hughes, 130 F.2d 810 (D.C. Cir. 1942) for an excellent and often cited presentation of the arguments opposing charitable immunity.

42. In recent years several states have overruled charitable immunity precedents. E.g., Noel v. Menninger Foundation, 175 Kan. 751, 267 P.2d 934 (1954); Pierce v. Yakima Valley Memorial Hospital Ass'n, 43 Wash. 2d 162, 260 P.2d 765 (1953); cases cited in Annot., 25 A.L.R.2d 29, 74-79 (1952).

When unable or unwilling to overrule hospital immunity outright, courts have imposed a number of limitations on the doctrine. Some states have held that charitable immunity does not apply where recovery may be had from liability insurance. E.g., O'Connor v. Boulder Ass'n, 105 Colo. 259, 96 P.2d 835 (1939) ; Moore v. Moyle, 405 I11. 555, 92 N.E.2d 81 (1950). Where a governmental hospital is held to have performed a proprietary or corporate function, governmental immunity will not be applied. Annot., 25 A.I.R.2d 203, 213-14 (1952). Most courts will apply tort immunity to personal injury cases brought in contract. See, e.g., Roosen v. Peter Bent Brigham Hospital, 235 Mass. 66, 126 N.E. 
reluctant to impose liability upon doctors or hospitals for defects they could in no way prevent or detect. ${ }^{43}$ This rationale seems to underlie the decision in the Bad Blood case. ${ }^{44}$ The force of this argument would be somewhat diminished in the Cutter cases by the counterargument that doctors and hospitals would be liable to their patients only as links in a chain of impleading that would ultimately lead back to the producer. ${ }^{45}$ The counterargument presupposes, however, that most courts would be willing to hold Cutter ultimately liable in implied warranty.

Many courts will hesitate to impose the strict liability of implied warranty on Cutter unless they believe that the presence of the infective virus could have been prevented. Decisions imposing warranties of fitness for human consumption traditionally have been grounded in a policy of protecting the health and life of the consumer by encouraging the prevention of defects the consumer

392 (1920). But see Armstrong v. Wesley Hospital, 170 I11. App. 81 (1912) (dictum). However, a contract suit for breach of warranty might be allowed where the hospital can implead the producer, who would be ultimately liable. Cf. note 45 inf $r a$ and accompanying text.

43. Retail druggists generally are not liable for injuries resulting from patent or proprietary medicines sold by them in sealed containers. E.g., West v. Emanuel, $198 \mathrm{~Pa}$.

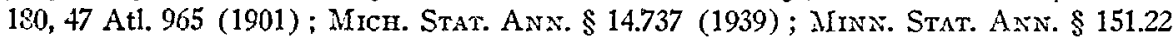
(1946). There would appear to be an even stronger policy against holding hospitals and doctors liable for injury from defective vaccines when it is apparent that the defect was in the vaccine when it left the producer.

In the case of ford, most jurisdictions allow implied warranty suits by the consumer against the retailer even though the defect is latent and the goods are in a sealed container. Only in seven states are such suits now denied. Drckerson, Producrs Liability and the Food Consumer 31, 50-51 (1951) (collecting citations). Those opposed to this warranty point out that the retailer has no greater knowledge of possible defects than the buyer, and the buyer knows this. See, c.g., Pennington v. Cranberry Fuel Co., 117 W. Va. 680, 186 S.E. 610 (1936) ; Waite, Retail Responsiblity-A Reply, 23 Mrnv. L. Rev. 612 (1939). The two best arguments for the retailer's liability are: he is in a position to decrease the likelihood of injury by selecting dependable suppliers, and he can serve as a useful conduit for transmitting liability back. Dicherson, op. cit. supra, at 87-89. In many cases it would be unjust to subject doctors or hospitals-or even retailers-to legal process simply to provide a conduit for the grievances of others. See Ehrenzweig, Negligence Withoct FAULT \$2-83 (1951). This would be especially true when there was a danger of impecunious intermediate parties insulating the conduit from access to the producer, or substantial problems of jurisdiction making the attempt to shift liability to the manufacturer both difficult and costly. However, these dangers and inconveniences must be balanced against the injustice that would result from barring an injured person from recovery on the technical ground of no privity.

44. "[I]f injury results ... where no negligence or fault is present, liability should not be imposed upon the institution or agency actually seeking to save or otherwise assist the patient." Perlmutter v. Beth David Hospital, 308 N.Y. 100, 107, 123 N.E.2d 792, 795 (1955). See note 34 supra.

45. Cutter could be impleaded as a third party defendant by the doctor or hospital. E.g., Davis v. Radford, 233 N.C. 283, 63 S.E.2d 822 (1951); CLARK, Code Pleading § 64 (2d ed. 1947) (collecting citations). The dissent in the Bad Blood case pointed out that the implied warranty suit should be allowed, especially because there was a third party defendant who would be ultimately liable. Perlmutter v. Beth David Hospital, supra note 44 , at 110,123 N.E.2d at 797. 
is ordinarily unable to discover. ${ }^{46}$ Implicit in this policy are two assumptions. The first is that manufacturers or distributors are in position to prevent or detect the occurrence of most defects. ${ }^{47}$ The second is that imposition of absolute liability without proof of fault is the best means of stimulating manufacturers and distributors towards the highest degree of preventive diligence. ${ }^{\text {\& }}$ Many courts may conclude that neither assumption is applicable to the Cutter situation: the injuries appear to be due to an unavoidable accident which no feasible degree of diligence would have prevented; and neither the manufacturer nor the distributor was in a better position to prevent the accident than the consumer. ${ }^{49}$ Courts reaching this conclusion are likely to fall back upon the

46. In imposing an implied warranty for human consumption, the courts emphasize the manufacturer's or restaurant's ability to prevent the existence of harmful defects and the consumer's comparative helplessness. E.g., Cushing v. Rodman, 82 F.2d 864 , $868-69$ (D.C. Cir. 1936) (pebble in roll); Wiedeman v. Keller, 171 I1l. 93, 99, 49 N.E. 210, 211 (1897) (infected meat); Walters v. United Grocery Co., 51 Utah 565, 568, 172 Pac. 473, 474 (1918) (stale potato salad). But sce Kenower v. Hotels Statler Co., 124 F.2d 658 (6th Cir. 1942) (plaintiff sues hotel for serving clams infectcd with typhoid; liability although there was apparently no way for either the original supplier or the hotel to see that the clams were not infected). Kenower appears to be the only case in which warranty liability has been imposed for an unpreventable defect.

47. E.g., Jacob E. Decker \& Sons v. Capps, 139 Tex. 609, 621, 164 S.W.2d \$2\$, \$34 (1942) (contaminated meat) ; Dryden v. Continental Baking Co., 11 Cal. 2d 33, 38, 77 P.2d 833, 835 (1938) (glass in loaf of bread). The party sued need not be the one who could have prevented the defect. E.g., Cushing v. Rodman, 82 F.2d 864 (D.C. Cir. 1936) (restaurateur held for pebble in roll it purchased from bakery). But cf. note 43 supra (sealed container doctrine applied in seven states).

In many older leading cases implied warranty is explicitly related to negligence. E.g., Davis v. Van Camp Packing Co., 189 Iowa 775, 176 N.W. 382 (1920) (beans); Hertzler v. Manshum, 228 Mich. 416, 200 N.W. 155 (1924) (impurity in flour).

48. "Restricting recovery by the injured member of the public to cases predicated upon negligence is a seriously inadequate means of securing the social interest in the individual safety, because of the greal difficulty of proof for the plaintiff." Cushing $v$. Rodman, 82 F.2d 864, 869 (D.C. Cir. 1936) ; see Jacob E. Decker \& Sons v. Capps, 139 Tex. 609, 621, 164 S.W.2d 828, 834 (1942) ; Escola v. Coca-Cola Bottling Co., 24 Cal. 2d 453, 462,150 P.2d 436, 441 (1944) (beverage bottle explodes in plaintiff's hand) (concurring opinion); note 53 infra.

49. See notes 1-6 supra and accompanying text. Nevertheless, some courts may impose warranty liability because they are convinced that live virus could not have been present in the vaccine if Cutter had been as vigilant as the potential danger required. For example, during the production of the Salk vaccine Cutter and other producers found more traces of inactivated virus than had been anticipated on the basis of the 1954 field trials. June Report, N.Y. Times, June 10, 1955, p. 12, col. 5. Spencer, Where Are We Now on Polio?, Saturday Evening Post, Sept. 10, 1955, p. 156. The manufacturers nevertheless failed to stop production in order to revaluate the process. Ibid. This failure seems unlikely to constitute actionable negligence, but some courts may consider it an indication of moral fault.

Other courts might conceivably base liability on prevention, even admitting Cutter's innocence. The threat of liability would tend to increase the scientific effort to develop absolutely safe standards in the future. Manufacturers would go beyond the safety standards which would normally be acceptable. This argument appears unconvincing, however, for Cutter and all concerned already had the highest incentives to produce a safe vaccine. 
doctrines of "privity" or "sale" rather than impose upon Cutter a warranty of scientific infallibility. ${ }^{50}$

Vaccine manufacturers should be held to strict liability in tort for all injuries directly resulting from the infective vaccine they produce. ${ }^{51}$ Strict liability would best assure compensation for the injured and best distribute the costs of compensation among those who benefit from the vaccine. ${ }^{52}$ It would also provide the producer with added incentive to prevent avoidable defects in the future. ${ }^{63}$ A flexible use of implied warranty doctrine might also serve to effectuate these policy goals. The utility of this doctrine is limited, however, by the fact that it is grounded in contract principles and policies which are unrelated to the social problem of personal injury. Therefore, courts which believe that policy requires imposition of liability upon Cutter would do the law a greater service by imposing it as strict liability in tort. These decisions would focus squarely upon the policies involved rather than upon irrelevant fictions. ${ }^{54}$ They would also establish clearly that manufacturers of products for human consumption are liable for personal injuries caused by their products, not because they are at "fault" for the injuries, nor because they would have prevented them, but because they can best distribute this unavoidable cost to all persons who benefit from the enterprise.

50. This is borne out by the Bad Blood decision. Perlmutter v. Beth David Hospital, 308 N.Y. 100, 123 N.E.2d 792 (1955). See notes 34, 35, 44 supra and accompanying text. But sec Kenower v. Hotels Statler Co., 124 F.2d 65S (6th Cir. 1942).

Some courts still refuse to impose an implied warranty on the retail transaction between dealer and consumer when the food is sold in "sealed containers." These decisions rest on the ground that the seller has no greater knowledge of possible defects than does the buyer. E.g., Bigelow v. Maine Cent. R.R., 110 Me. 105, 85 At1. 396 (1912) (canned asparagus served in dining car); see note 43 supra.

Courts unwilling to impose liability upon Cutter could base their decision on other grounds: drug manufacturers are not held to warrant to the consumer the safety of their products, see note 23 supra; the consumer could not be said to have "relied" on Cutter to prevent defects outside its control; Cutter should not pay for the negligence of the Government or scientists who developed the safety tests. Some courts may even argue that warranty liability is ultimately based on fault. Cf. note 47 supra.

51. It has been suggested that manufacturers of food products should also be held to absolute or strict liablity. E.g., Escola v. Coca-Cola Bottling Co., 24 Cal. 2d 453, 466, 150 P.2d 436, 442-43 (1944) (Traynor, J., concurring opinion); PRosser, ToRTs 510-11 (2d ed. 1955). Enrenzweig, op. cit. supra note 43, at 82-83 (1951) ; Dickerson, Products Liability AND the Food CONSUMER 279-80 (1951).

52. See notes 15-18 supra and accompanying text.

53. Imposing absolute liability without fault on the manufacturer places the liability on the party who is in the best position to reduce injury through negligently caused defects. "[C]onsciousness of liablity only where negligence can be shown is by no means as sharp an incentive to the service of good food as consciousness of absolute liability for service of bad." Cushing v. Rodman, 82 F.2d 864, 869, 871 (D.C. Cir. 1936). See note 48 supra. But cf. note 49 supra.

54. "[F]ictions are not necessary to fix the manufacturer's liability under a warranty if the warranty is severed from the contract of sale between the dealer and the consumer and based on the law of torts ... as a strict liability." Escola v. Coca-Cola Bottling Co., 24 Cal. 2d 453, 466, 150 P.2d 436, $442-43$ (1944) (Traynor, J., concurring opinion). See notes 29, 31, 39 supra. 